\title{
The Influence of Breed and Type of Extender on the Quality of Bull Semen
}

\author{
Iman Sukirman $^{1}{ }^{*}$, Eros Sukmawati $^{1},{\text { Siti Darodjah } \text { Rasad }^{2} \text { and Nurcholidah Solihati }}^{2}$ \\ ${ }^{1}$ Lembang Artificial Insemination Center, Bandung Barat, Indonesia \\ ${ }^{2}$ Animal Reproduction and AI Laboratory, Animal Science Faculty, Padjadjaran University, Sumedang, Indonesia \\ *Corresponding author email: mantrimakter2@gmail.com
}

\begin{abstract}
This study aimed to determine the influence of breed and type of extenders on frozen semen quality of cows at BIB Lembang. The experimental study was conducted in a Factorial Randomized Block Design (RBD) with two factors. The first factor was four cow breeds, i.e. Ongole Cross (PO), Brahman (BR), Simmental (SM) and Limousin (LM), and the second factor was two types of extender, i.e. Skim-Egg Yolk (SKT) and AndroMed ${ }^{\oplus}$ (AND), all repeated four times. The observed variables were percentage of spermatozoa motility and intact plasma membrane (IPM). All data obtained were analyzed using a general linear model (IBM SPSS ver. 23). The results demonstrated an interaction between breed and the type of diluent to motility. Breeds showed significantly different motility but non-significantly different intact plasma membrane (MPU) of semen. The type of diluent did not significantly affect motility and intact plasma membrane (MPU) of the frozen semen. The effect of the breed on BR motility was lower and significantly different from PO, LM and SM. The types of diluent did not significantly affect motility, MPU. The results showed that SKT was lower than AND, it was indicative effect of breed on intact plasma membrane (MPU) PO was lower than BR, LM and SM and the effect of the type of diluent on whole plasma membrane (MPU) AND is lower than SKT. It can be concluded that breed influences the motility of semen. The lowest motility reduction in frozen semen is Brahman cattle by using skim-egg yolk extender.
\end{abstract}

Keyword: breed, diluents type, motility, intact plasma membrane

Abstrak. Penelitian ini bertujuan untuk mengetahui pengaruh bangsa dan jenis pengencer terhadap kualitas semen beku sapi pejantan unggul. Rancangan percobaan yang digunakan yaitu Rancangan Acak Kelompok (RAK) faktorial. Faktor pertama empat bangsa yaitu sapi Peranakan Ongole (PO), Brahman (BR), Simmental (SM) dan Limousin (LM), faktor kedua yaitu dua jenis pengencer Skim-Kuning Telur (SKT) dan AndroMed ${ }^{\circ}$ (AND) yang diulang sebanyak empat kali. Peubah yang diamati meliputi penurunan persentase motilitas spermatozoa dan membran plasma utuh (MPU). Data yang diperoleh dianalisis menggunakan general linear model (IBM SPSS ver 23). Hasil penelitian menunjukkan bahwa terdapat interaksi antara bangsa dan jenis pengencer terhadap motilitas, bangsa menunjukkan perbedaan nyata terhadap motilitas tetapi berbeda tidak nyata terhadap membran plasma utuh (MPU) semen. Jenis pengencer menunjukkan perbedaan yang tidak nyata terhadap motilitas dan membran plasma utuh (MPU) semen yang dibekukan. Pengaruh bangsa terhadap motilitas BR lebih rendah dan berbeda nyata dibandingkan PO, LM dan SM. Pengaruh jenis pengencer tidak memberikan perbedaan yang nyata terhadap motilitas MPU. Hasil penelitian menunjukkan bahwa SKT lebih rendah dibandingkan AND ini ditunjukkan bahwa pengaruh bangsa terhadap membran plasma utuh (MPU) PO lebih rendah dibandingkan BR, LM dan SM dan pengaruh jenis pengencer terhadap membran plasma utuh (MPU) AND lebih lebih rendah dibandingkan SKT. Dapat disimpulkan bahwa bangsa berpengaruh terhadap motilitas semen. Penurunan motilitas terendah pada semen beku sapi Brahman dengan menggunakan jenis pengencer skim-kuning telur.

Kata kunci: bangsa, jenis pengencer, motilitas, membran plasma utuh

\section{Introduction}

Reproductive technology, such as artificial insemination, has been implemented to accelerate and improve genetic quality. Artificial insemination is a technique to transfer semen from bull to female reproductive tract with special equipment.
Artificial insemination is superior because it enables a more effective and efficient cattle mating or breeding, and superior semen could better fertilize the female cows in artificial insemination than the natural mating (Wahyuningsih et al., 2013) and 3 to 4 times faster to improve the genetic quality (Arifiantini et al., 2005). One of the critical 
factors of an artificial insemination program is frozen semen. The quality of frozen semen is determined by various factors such as freezing technique, type of dilution or extender, and type and concentration of cryoprotectant (Ariantie et al., 2013). Semen diluents can maintain the quality of spermatozoa during cooling, freezing, and thawing process (Aboagla and Terada, 2004), and the best diluent should be able to reduce the impairment rate of sperm motility (Zega et al., 2015).

Commercial diluents are composed of varied ingredients and formulation, such as AndroMed $^{\circledR}$ (Minitube, Germany) which is based on lecithin from soybeans (Arifiantini and Yusuf, 2010). Semen diluents have varied components which reflect different capabilities to support spermatozoa survival (Solihati et al., 2008) and each diluent exhibits specialty (Paulenz et al., 2002). Accordingly, the variation of extender's components may affect semen quality differently across breeds. There is an interaction between cattle breed and type of extender because the physiological aspects of cattle breed may influence the semen quality.

\section{Material and Methods}

\section{Time and Location of Research}

This research was conducted from December 22, 2017 to January 5, 2018 in the production laboratory of Artificial Insemination Center Lembang, West Bandung regency, West Java Province.

\section{Research Objective}

This research used semen from four eightyear-old bulls (Ongole cross breed/PO, Brahman/BR, Simmental/SM and Limousin Cross breed/LM). Semen was collected twice a week. Feeding consisted of $1 \mathrm{~kg}$ African grass hay, $4 \mathrm{~kg}$ concentrate, $15 \mathrm{~g}$ feed mix, $7 \mathrm{~g}$ mineral Selenium, and $50 \mathrm{~kg}$ elephant grass.

\section{Research Method}

\section{Preparation of Semen Diluents}

The first type of extender/dilution - skim egg yolk (SEY) - was prepared one day before semen collection, stored in refrigerators at $4^{\circ} \mathrm{C}$ and divided into two parts. Part A $(500 \mathrm{ml})$ consisted of $500 \mathrm{~g}$ of skim milk (Tropicana Slim) dissolved with $500 \mathrm{ml}$ aquadest and heated at $90-92^{\circ} \mathrm{C}$ for 10 minutes. After temperature stayed at $5^{\circ} \mathrm{C}$, antibiotics (Penicillin 100,000 IU and Streptomycin 100 $\mathrm{mg}$ in $10 \mathrm{ml}$ aquadest solution) were incorporated into the solution with a 1:100 ratio. The solution was reduced to $475 \mathrm{ml}$ and added $25 \mathrm{ml}$ egg yolk. Part B $(500 \mathrm{ml})$ consisted of $10 \mathrm{~g}$ glucose, $25 \mathrm{ml}$ egg yolk, 80 $\mathrm{ml}$ glycerol and $385 \mathrm{ml}$ aquabidest. The second type of extender, the AndroMed ${ }^{\circledR}$ diluents (AND), was made before semen collection with 1:4 ratios.

\section{Semen Collection and Evaluation}

Semen was collected twice a week in the morning using an artificial vagina for macroscopical and microscopical evaluation. Microscopic evaluation includes concentration using SDM 5, mass movement by putting a fresh drop of semen onto an object glass for microscopic observation with 200x magnification (Olympus BX 53) or screen observation.

Individual motility was measured by dripping semen on top of object glass, added with 4-5 drops of physiological $\mathrm{NaCl}$, homogenized and sealed with a glass cover for microscopic observation using a 200x magnification (Olympus BX 53) and heating table $\left(37^{\circ} \mathrm{C}\right)$ or through a monitor screen.

The Integrity of plasma membrane (IPM) was evaluated with Hypoosmotic Swelling Test (HOS) solution. Semen was mixed with HOS solution (1:100 ratio), homogenized and incubated for $30-45 \mathrm{~min}$ at $37^{\circ} \mathrm{C}$. Under a microscopic observation (Olympus BX 53) with 400 times magnification, at least 200 
spermatozoa were calculated in 10 fields of view. Sperm with an intact plasma membrane is characterized by a circular or bulging tail, whereas the damaged one has a straight tail.

\section{Dilution and Equilibration}

The examined semen was divided into two parts and each diluted with SEY and AND diluents slowly at a dose of 25 million/ $0.25 \mathrm{ml}$ (minitube). The diluted semen was inserted into the cooltop for $4 \mathrm{~h}$ equilibration.

\section{Filling and Sealing}

A straw (minitube, $0.25 \mathrm{cc}$ ) was coded using an automatic printing machine and contained the semen. The end of the straw was closed using an automatic filling sealing machine.

\section{Freezing}

The straw was placed on a special rack and inserted into an automatic freezing machine for 9 minutes. The straw is removed from the rack into the goblet and then immersed in nitrogen.

\section{Storage}

The goblet of frozen semen was inserted into a canister inside a container of liquid nitrogen and let sit for 24 hours.

\section{Thawing of the Frozen Semen}

The semen was thawed 24 hours after being stored at $37^{\circ} \mathrm{C}$ for 30 seconds, then evaluated for motility and intact plasma membrane (IPM) percentage.

\section{Data Analysis}

The data was analyzed in a factorial randomized block design followed by Duncan Test for difference across treatments and interactions (Gaspersz, 1995).

\section{Result and Discussion}

\section{Fresh Semen Characteristic}

The fresh Bull's semen was good according to the standard quality. Ax et al. (2008) stated that Bull's sperm concentration ranged between $2 \times 10^{8}$ and $1.8 \times 10^{9} \mathrm{sperm} / \mathrm{ml}$, and the average progressive motility was $60-75 \%$ (Table 1).

\section{Semen Quality after Treatment}

During thawing and frozen semen production (collection, dilution, equilibration, freezing and storage) a series of change was observed in the temperature, osmotic pressure changes, ice formation and dissolution in extracellular environments (Watson, 2000) which may damage cell, decrease sperm motility, viability, integrity of the plasma membrane, and damage DNA spermatozoa (Priyanto et al., 2015).

\section{Effect of Breeds on Semen Quality}

Statistical analysis showed a significant difference $(P<0.05)$ between breeds and types of extender. Table 3 illustrates a decreasing percentage of semen motility across breeds. The highest motility decrease occurred in Simmental (SM) (35.00 \pm 9.63) which was significantly different from PO and Limousin (26.87 \pm 5.30$)$ and Brahman (18.75 \pm 12.75$)$. The decrease was within the reasonable limit which, according to Parrish (2003), was 10$40 \%$, and $33.27 \pm 5.57 \%$ in Pasundan Cattle (Baharun et al., 2017).

Mostari et al. (2004) reported that different breeds showed varied percentage of motility due to differences in energy source composition in seminal plasma (Rahmawati et al., 2015). Accordingly, the declining motility was influenced by breeds as a semen producer.

The results showed that breeds did not impose a significantly different effect on the decrease of intact plasma membrane (IPM) $(P>0.05)$. The lowest decrease in PO (16.90 \pm 1.72) was lower than a study by Gunawan et al. (2004), i.e. $46.68 \%$. The highest rate of decrease in IPM was observed in Simmental (18.07 \pm 1.88$)$, which was lower than $21.25 \pm$ 6.86 by Sukmawati et al. (2014). 
Table 1. Average of fresh semen qualities of bulls

\begin{tabular}{lcccc}
\hline \multicolumn{1}{c}{ Breed } & PO & BR & LM & SM \\
\hline Color & White milk & Cream & White milk & White milk \\
Volume $(\mathrm{ml})$ & 6.44 & 4.44 & 4.88 & 6.19 \\
$\mathrm{pH}$ & 6.65 & 6.59 & 6.76 & 6.52 \\
Mass movement & ++ & ++ & ++ & ++ \\
Concentration $\left(10^{6} / \mathrm{ml}\right)$ & 1082 & 1501.75 & 1309.25 & 1545.75 \\
Motility (\%) & 70 & 71.25 & 70 & 80 \\
IPM (\%) & 79.27 & 81.13 & 87.31 & 86.26 \\
\hline
\end{tabular}

Note: Ongole Cross (PO), Brahman (BR), Simmental (SM) and Limousin (LM)

Table 2. Average of post-thawing semen quality of different breeds and types of extender

\begin{tabular}{lcccc}
\hline & \multicolumn{4}{c}{ Post thawing } \\
\cline { 2 - 5 } Breed & \multicolumn{2}{c}{ Skim egg yolk (SEY) } & \multicolumn{2}{c}{ Andromed (AND) } \\
\cline { 2 - 5 } & Motility (\%) & IPM (\%) & Motility (\%) & IPM (\%) \\
\hline PO & 40 & 63.51 & 46.25 & 61.23 \\
BR & 61.25 & 64.63 & 41.25 & 62.54 \\
LM & 41.25 & 67.83 & 48.75 & 70.65 \\
SM & 41.25 & 66.63 & 45 & 70.76 \\
\hline
\end{tabular}

Note: Ongole Cross (PO), Brahman (BR), Simmental (SM) and Limousin (LM)

Table 3. Average decreased of sperm motility across bull's breeds

\begin{tabular}{cc}
\hline \multicolumn{2}{c}{ Average Decrease= of Sperm Motility (\%) } \\
\hline Breed & Average \\
\hline Ongole Cross (PO) & $26.87 \pm 5.94^{\mathrm{b}}$ \\
Brahman (BR) & $18.75 \pm 12.75^{\mathrm{a}}$ \\
Simmental (SM) & $35.00 \pm 9.64^{\mathrm{c}}$ \\
Limousin (LM) & $26.87 \pm 5.30^{\mathrm{b}}$ \\
\hline Note: Different superscripts within column show significant difference (P<0.05). \\
Table 4. Average decrease of intact plasma membrane (IPM) across bull's breeds. \\
\hline Breed & Average Decrease of IPM (\%) \\
\hline Ongole Cross (PO) & Average \\
Brahman (BR) & $16.90 \pm 1.72^{\mathrm{a}}$ \\
Simmental (SM) & $17.54 \pm 2.28^{\mathrm{a}}$ \\
Limousin (LM) & $18.07 \pm 1.88^{\mathrm{a}}$ \\
\hline
\end{tabular}
Note: Different superscripts within column showed significant difference $(\mathrm{P}<0.05)$

Many changes in this frozen semen processing may damage sperm cells and decrease plasma membrane integrity (Priyanto et al., 2015; Watson, 2000). An extreme temperature and osmolarity changes affected the configuration of lipid membrane structures and lipid compositions that interfere with their permeability and function (Moce and Graham, 2006; Cooter et al., 2005; Watson, 2000). Spermatozoa in each animal species have different membrane compositions; therefore, they demonstrate different resistance to cooling and freezing (Sukmawati et al., 2014). 
Effect of extender types on semen quality

Table 5. Average percentage decrease of motility and IPM at different types of extender

\begin{tabular}{lcc} 
& \multicolumn{3}{c}{ Decrease of quality } \\
\cline { 2 - 3 } Extender & Motility & IPM \\
\hline SEY & $26.25 \pm 12.97^{\mathrm{a}}$ & $17.84 \pm 2.26^{\mathrm{a}}$ \\
AND & $27.50 \pm 7.07^{\mathrm{a}}$ & $17.20 \pm 2.26^{\mathrm{a}}$ \\
\hline
\end{tabular}

Note: Different superscript in the same column was significantly different $(\mathrm{P}<0.05)$.

Table 5 shows that there has different not significant effect of the extender or diluent type on the decrease of motility and intact cemented plasma membrane (IPM) of semen $(P>0.05)$. The decreasing rate of motility in SEY diluent was lower than in AND because spermatozoa metabolized glucose in SEY (Gunawan et al., 2004) as an energy source to reserve motility and maintain lifespan (Widjaya, 2011).

Skim milk as a buffer can well maintain the changeable $\mathrm{pH}$ due to the formation of residual lactic acid metabolism to produce energy. Also, unlike soybeans, egg yolk contains $0.6 \%$ carbohydrate that could maintain spermatozoa motility (Kusumawati and Leondro, 2011). According to Gunawan at al. (2004), the rate of motility decrease in Skim-egg yolk dilution was lower than AND in PO cattle. It was in contrast with Arifiantini and Yusuf (2004) who argued that the best motility of AND diluent was on FH bull, and Baharun et al. (2017) on Pasundan cattle. The
Rate of IPM decrease in AND extender was lower than SEY diluent which demonstrated the effect of lecithin in egg yolks as an anticold shock (Aboagla and Terada, 2004; Gunawan et al., 2004) and membrane coatings (Rezki et al., 2016) to maintain IPM. However, Moussa et al., (2002) reported that lecithin from soybeans contained lower lipoprotein density (HDL) than egg yolks, which inhibited spermatozoa respiration. Similarly, Ghareeb, et al. (2017) stated that AND diluent demonstrated the best plasma membrane in Brangus-Hereford cattle.

Temperature changes induce stress on the membrane because the lipid phase and membrane function also change (Watson, 2000). Lecithin can retain and protect spermatozoa from cold stress (Permatasari et al., 2013) and this could also happen in lipoprotein density (HDL) of IPM (Anwar et al., 2015). Lecithin derived from egg yolk in SEY diluent and from soybean in AND demonstrate similar ability to maintain IPM of spermatozoa.

\section{Effect of interaction between breed and type of extender on semen quality}

Table 6. Value of interaction between breeds and type of extender on decrease of motility

\begin{tabular}{|c|c|c|}
\hline \multirow{2}{*}{ Breed } & \multicolumn{2}{|c|}{ Extender } \\
\hline & SEY & AND \\
\hline PO & $\underset{B}{30,00^{a}}$ & $\underset{A}{23,75^{a}}$ \\
\hline $\mathrm{BR}$ & $\underset{A}{10,00^{a}}$ & $\underset{A}{30,00^{a}}$ \\
\hline SM & $\underset{c}{38,75^{a}}$ & $\frac{31,25^{a}}{A}$ \\
\hline LM & $\underset{B}{28,75^{a}}$ & $\underset{A}{25,00^{a}}$ \\
\hline
\end{tabular}

Information: Different superscripts within column show significant difference $(\mathrm{P}<0.05)$ 
Table 7. Interaction value between breed and type of extender on IPM

\begin{tabular}{|c|c|c|}
\hline \multirow{2}{*}{ Breed } & \multicolumn{2}{|c|}{ Extender } \\
\hline & SEY & AND \\
\hline PO & $\underset{A}{15,76^{a}}$ & $\underset{A B}{18,04^{b}}$ \\
\hline$B R$ & $16,50^{a}$ & $\underset{B}{18,59^{a}}$ \\
\hline SM & $\underset{B}{19,48^{b}}$ & $\underset{A B}{16,66^{a}}$ \\
\hline LM & $\underset{B}{19,62^{b}}$ & $\underset{A}{15,49^{a}}$ \\
\hline
\end{tabular}

Note: Different superscript in the same column was significantly different $(P<0.05)$

There is interaction between breed and dilution or extender type on the decrease of motility $(P<0.05)$. The interaction between breed and the dilution type on the decrease of motility with the combination of BR using SEY diluent showed the lowest rate of decrease of the motility, while the highest rate of decrease of motility occurred in combination of SM with SEY dilution.

There is an interaction between breed and dilution type on the decrease of IPM $(P<0.05)$. The interaction between breed and combined LM-AND dilution showed the lowest intersection rate of IPM, whereas the highest rate of IPM occurred in LM using SEY diluent.

\section{Conclusions}

It can be concluded that (1) breed has significant effect on decreasing of the motility, but not on the IPM; (2) types of diluent had no significant effect on the decreasing of motility and IPM; (3) there was an interaction between breeds and type of diluent in decreasing motility and IPM. The best combination was SEY diluents for BR bull, whereas AND diluent for LM demonstrated the optimum decrease of motility and IPM.

\section{Acknowledgment}

The authors express their gratitude to the Ministry of Agriculture of the Republic of Indonesia through the Agency for Extension and Development of Human Resources of Agriculture (BPPSDMP) for the research grant, and the Head and Staff of Artificial Insemination Agency Lembang for enabling the research site.

\section{References}

Aboagla, E. M. E. and T. Terada. 2004. Effects of Egg Yolk during the Freezing Step of Cryopreservation on the Viability of Goat Spermatozoa. Theriogenology. 62(2004):11601172.

Anwar, P., Y. S. Ondho and D. Samsudewa. 2015. Kualitas Membran Plasma Utuh Dan Tudung Akrosom Utuh. Agromedia. 33(1):53-63.

Ariantie, O. S., T. L. Yusuf, D. Sajuthi and R. I. Arifiantini. 2013. Effect of Glycerol and Dimethylformamide Cryoprotectants on Buck Etawah Crossbreed Frozen Semen Using Modified Tris Diluents. Jurnal IImu Ternakdan Veteriner. 18(4):239-250.

Arifiantini, I. and T. L. Yusuf. 2004. Keberhasilan Penggunaan Tiga Pengencer Dalam Dua Jenis Kemasan pada Proses Pembekuan Semen Sapi Frisien Holstein. Fakultas Kedokteran Hewan, Institut Pertanian Bogor.

Arifiantini, I. and T. L. Yusuf. 2010. Developing of Tris Soy Milk Diluent for Frisian Holstein Bull Frozen Semen. HAYATI Journal of Biosciences. 17(2):91-94.

Arifiantini, I., T. L. Yusuf and N. Graha. 2005. Longivitas dan Recovery Rate Pasca Thawing Semen Beku Sapi Fresian Holstein Menggunakan Bahan Pengencer Berbeda. Buletin Peternakan. 29(2): 53-61.

Ax, R. L., M. Dally, B. A. Didion, R. W. Lenz, C. C. Love, D. D. Varner, B. Hafez and M. E. Bellin. 2008. Semen Evaluation. B Hafez, ESE Hafez, Reproduction in Farm Animals. 7th edition. Lippincott Williams and Wilkins, Philadelphia. 365-368, 378.

Baharun, A., I. Arifiantini and T. L. Yusuf. 2017. Freezing Capability of Pasundan Bull Sperm Using Tris-Egg Yolk, Tris-Soy, and Andromed ${ }^{\circledR}$ 
Diluents. Jurnal Kedokteran Hewan. 11(1):4549.

Cooter, P. Z., H. A. Goolsby, S. D. Prien. 2005. Preliminary Evaluation of a Unique Freezing Technology for Bovine Sperm Cryopreservation. Reprod Dom Animal. 40:98-99.

Gaspersz, V. 1995.Teknik Analisis dalam Penelitian Percobaan. Penerbit Tarsito. Bandung.

Ghareeb, S., W. Haron, R. Yusoff, N. Yimer, F. Baiee, T. Ahmedeltayeb and M. Ebrahimi. 2017. PostThaw Evaluation of Cryopreserved Bull Semen Extended In Four Different Semen Extenders. Australian Journal of Basic and Applied Sciences. 11(5):80-87.

Gunawan, M., F. Afiati, E. M. Kaiin, S. Said and B. Tappa. 2004. Pengaruh media Pengencer Terhadap Kualitas Spermatozoa Beku Sapi PO. Seminar Nasional Teknologi Peternakan dan Veteriner. 61-66.

Kusumawati, E. D. and H. Leondro. 2011. Kualitas Semen Segar Sapi Pejantan Pada Penyimpanan dan Lama Simpan yang Berbeda. Jurnal Veteriner. 15(1):433-439.

Moce, E. and J. K. Graham. 2006. CholesterolLoaded Cyclodextrins Added to Fresh Bull Ejaculatesimprove Sperm Cryosurvival. J. Anim. Sci. 84:826-833.

Mostari, M. P., M.G.M. Rahman, M.A.M.Y. Khandoker and S.S. Husain. 2004. Evaluation of Bulls Based on Semen Quality and Herd Fertility. Pakistan Journal of Biological Scinces. 7(12):2177-2181.

Moussa, M., V. Martinez, A. Trimeche, D. Tanturier and M. Anton. 2002. Low Density Lipoprotein Extracted From Hen Egg Yolk By an Easy Method: Cryoprotective effect on FrozenThawed Bull Semen. Theriogenology. 57:15911762.

Parrish, J. 2003. Techniques in Domestic Animal Reproduction - Evaluation and Freezing of Semenhttp://www.wisc.edu/ansci_repro/(acce sed: January25 2018).

Paulenz, H., L. Soderquist, R. P. Perez and K. A. Berg. 2002. Effect of Different Extender and Storage Temperatures on Sperm Viability of Liquid Ram Semen. Theriogenology. 57:823836.

Permatasari, W. D., E. T. Setiatin, and D. Samsudewa. 2013. Studi Tentang Pengencer
Kuning Telur dan Pengaruhnya Terhadap Kualitas Semen Beku Sapi Jawa Brebes. Animal Agriculture Journal. 2(1):143 - 151.

Priyanto, L., R. I. Arifiantini and T. L. Yusuf. 2015. Deteksi Kerusakan DNA Spermatozoa Semen Segar dan Semen Beku Sapi Menggunakan Pewarnaan Toluidine Blue. Jurnal Veteriner. 16(1):48-55.

Rahmawati, M. A., T. Susilawati and M. N. Ihsan. 2015. Kualitas Semen dan Produksi Semen Beku pada Bangsa Sapi dan Bulan Penampungan yang Berbeda. Jurnal IImu-IImu Peternakan 25 (3): $25-36$.

Rezki, Z. M., D. Samsudewa and Y. S. Ondho. 2016. Pengaruh Pengencer Kombinasi Sari Kedelai dan Tris terhadap Kualitas Mikroskopis Spermatozoa Pejantan Sapi PO Kebumen. Jurnal Sain Peternakan Indonesia. 11(2):67-74.

Solihati, N., R. Idi, S. D. Rasad, M. Rizal, and M. Fitriati. 2008. Kualitas Sperma Cauda Epididimis Sapi Peranakan Ongole (PO) dalam Pengencer Susu, Tris dan Sitrat Kuning Telur pada Penyimpanan $4-5^{\circ} \mathrm{C}$. Animal Production. 10(1):22-29.

Sukmawati, E. 2014. Daya Tahan Spermatozoa terhadap Proses Pembekuan pada Berbagai Jenis Sapi Pejantan Unggul. Tesis. Sekolah Pascasarjana. Institut Pertanian Bogor.

Wahyuningsih, A., D. M. Saleh and Sugiyatno. 2013. Pengaruh Umur Pejantan dan Frekuensi Penampungan Terhadap Volume dan Motilitas Semen Segar Sapi Simmental di Balai Inseminasi Buatan lembang. Jurnal Ilmiah Peternakan. 1(3): 947-953.

Watson, P. F. 2000. The Causes of Reduced Fertility with Cryopreserved Semen. Animal Reproduction Science 60-61_2000. 481-492.

Widjaya, N. 2011. Pengaruh Pemberian Susu Skim dengan Pengencer Tris Kuning Telur Terhadap Daya Tahan Hidup Spermatozoa Sapi pada Suhu Penyimpanan $5^{\circ}$ C. Sains Peternakan. 9(2):7276.

Zega, I., S. Ilyas and S. Hutahaean. 2015. Kualitas Spermatozoa Sapi Limousin Dalam Pengencer Two-Stetm Extender Dengan Suplementasi Kuning Telur Bebek Selama Penyimpanan Pada Refrigerator. Jurnal Biosains. 1(3):66-72. 